\title{
EFFECTIVE MANAGEMENT STRATEGIES AGAINST LATE BLIGHT OF POTATO
}

\author{
Ashis Chakraborty ${ }^{1}$ and Hirak Banerjee ${ }^{2^{*}}$ \\ ${ }^{1}$ AICRP on Potato, Directorate of Research, BCKV, Kalyani-741235 \\ Nadia, West Bengal, India \\ ${ }^{2}$ Regional Research Station (CSZ), BCKV, Kakdwip-743347 \\ South 24-Parganas, West Bengal, India
}

\begin{abstract}
A field experiment was conducted during 2012-13 and 2013-14 crop season to find out the most effective strategies for management of late blight of potato. It was observed that prophylactic spray with mancozeb @ $0.2 \%$ followed by fenamidone + manozeb @ $0.3 \%$ as $2^{\text {nd }}$ spray at the onset of the disease followed by mancozeb @ $0.2 \%$ as $3^{\text {rd }}$ spray seven days after application of the $2^{\text {nd }}$ spray followed by one more spray with fenamidone+mancozeb @ $0.3 \%$ as $4^{\text {th }}$ spray seven days after application of $3^{\text {rd }}$ spray exhibited best management of late blight of potato in terms of percent reduction of disease over control which was 83.64 and $84.79 \%$ in 2012-13 and 2013-14 crop season, respectively. The total tuber yield was also highest in this treatment showing 25.84 and $26.78 \mathrm{t} \mathrm{ha}^{-1}$ during 2012-13 and 2013-14 crop season, respectively.
\end{abstract}

Keywords: Effective management, fenamidone+ mancozeb, late blight of potato.

\section{INTRODUCTION}

Late blight of potato is one of the most dreaded diseases wherever potato is grown. During mid 1800, the disease caused wide-spread crop failure throughout the Northern Europe including Ireland where it was responsible for the famous Irish Famine in 1845 (Elansky et al., 2001). In West Bengal the disease was first noticed in Darjeeling district in 1883. In the plains, the disease was first noticed in Hooghly districts during 1898-1900.

Today the disease is a recurring feature in plains of West Bengal. It occurs in mild to moderate form every year but assumes severe form and develop epidemic only in occasions. Yield losses in the plains have been estimated around 10-75\% (Dutt, 1979). Management of the disease is a great challenge to the plant pathologists

\footnotetext{
* Corresponding author email: aicrpp.bckv@gmail.com
}

Received: 04.05.2016 
all over the world. This is due to the unique capacity of pathogen to cause cell death of the host and this happens so fast that within 2-4 days the entire crop collapse under favourable weather condition.

The resistant variety is the only cheapest and environment friendly approach to combat the disease but the pathogen is highly variable and changes itself with a slight change in the environment. The host genotype resistance in most of the varieties is broken within few years of their cultivation. Therefore, the most effective alternative is the need based use of chemical fungicide for management of the disease (Singh et al., 2003).

Among the fungicides the most effective is systemic one. But indiscriminate use of fungicides also has adverse effect on resistance as the pathogen develops resistance against the systemic fungicides. Therefore, it is not advisable to use only one or two systemic fungicides for long-term basis, instead the fungicides should be changed after few years and newer molecules should be introduced in its place to avoid development of resistance in the pathogen. Keeping these views in mind the present investigation was carried out to develop an effective spray schedule for the most effective management of the disease.

\section{MATERIALS AND METHODS}

The experiment was conducted at Adisaptagram Block seed Farm, Hooghly, West Bengal during 2012-13 and 2013-14 crop seasons. The planting was done in November each year. Two varieties like Kufri Chandramukhi $\left(\mathrm{V}_{1}\right)$ and Kufri Jyoti $\left(\mathrm{V}_{2}\right)$ were used for this experiment. The experiment was laid out following a randomized block design with 4 replications and 6 treatments. The unit plot size was $5 \mathrm{~m} \times 2 \mathrm{~m}$ and potato seeds were planted in line maintaining $60 \mathrm{~cm} \times 20 \mathrm{~cm}$ spacings. Prophylactic foliar sprays were applied just at the time of canopy closure i.e. 45-50 days after planting according to the details of spray schedules shown below.

$\mathrm{T}_{1}=$ Spray with mancozeb @ $0.2 \%$ followed by 2 more spray with mancozeb @ $0.2 \%$ at weekly intervals starting from onset of the disease.

$\mathrm{T}_{2}=$ Spray with mancozeb @ $0.2 \%$ followed by 3 more sprays with mancozeb @ $0.2 \%$ at weekly intervals starting from onset of the disease.

$\mathrm{T}_{3}=$ Spray with mancozeb @ 0.2\% followed by cymoxanil + mancozeb @ $0.3 \%$ as $2^{\text {nd }}$ spray at the onset of the disease followed by mancozeb @ $0.2 \%$ as $3^{\text {rd }}$ spray seven days after the application of $2^{\text {nd }}$ spray followed by one more with cymoxanil + mancozeb @ $0.3 \%$ as $4^{\text {th }}$ spray seven days after application of $3^{\text {rd }}$ spray.

$\mathrm{T}_{4}=$ Spray with mancozeb @ $0.2 \%$ followed by fenamidone + mancozeb @ $0.3 \%$ as $2^{\text {nd }}$ spray at the onset of the disease followed by mancozeb @ $0.2 \%$ as $3^{\text {rd }}$ seven days after the $2^{\text {nd }}$ spray followed by one more spray with fenamidone + mancozeb $0.3 \%$ as $4^{\text {th }}$ spray seven days after application of $3^{\text {rd }}$ spray. 
$\mathrm{T}_{5}=$ Spray with mancozeb @ 0.2\% followed by dimethomorph + mancozeb @ $0.3 \%$ as $2^{\text {nd }}$ spray at the onset of the disease followed by one more spray with mancozeb @ $0.2 \%$ as $3^{\text {rd }}$ spray seven days after the $2^{\text {nd }}$ spray followed by one more spray with dimethomorph + mancozeb @ $0.3 \%$ as $4^{\text {th }}$ spray seven days after application of $3^{\text {rd }}$ spray.

$\mathrm{T}_{6}=$ Control (no fungicidal spray)

In each plot 50 plants were selected randomly and in each plant one top leaf, one middle leaf and one lower leaf were selected for estimation of severity of the disease. The data on severity of the disease was recorded before every spray following 0-9 scale as developed by Malcolimson (1976) based. The details of which are shown below.

$\begin{array}{cc}\text { Percent leaf area infected }(\%) & \text { Score } \\ 0 & 0 \\ 1-9 & 1 \\ 10 & 2 \\ 11-25 & 3 \\ 26-40 & 4 \\ 41-60 & 5 \\ 61-70 & 6 \\ 71-80 & 7 \\ 81-90 & 8 \\ 91-100 & 9\end{array}$

Thereafter, the percent disease index (PDI) was calculated following the formula developed by McKinney (1923)

PDI $=\underline{\text { Sum of all numerical ratings }} \times 100$

Total No. of leaves Examined $\times$ Maximum Grade

\section{RESULTS AND DISCUSSION}

At 7 days of first appearance of the disease, visible symptoms of late blight appeared only under control $\left(\mathrm{T}_{6}\right)$ where the PDI was 18.42 in variety Kufri Chandramukhi $\left(\mathrm{V}_{1}\right)$ and 17.90 in variety Kufri Jyoti $\left(\mathrm{V}_{2}\right)$. In $\mathrm{V}_{1}$, the lowest disease severity (PDI) was recorded from $\mathrm{T}_{4}$ followed by $\mathrm{T}_{5}, \mathrm{~T}_{3}, \mathrm{~T}_{2}$ and $\mathrm{T}_{1}$ at 14, 21 and 28 days after first spray. At 28 days after first appearance of the disease, the reduction in PDI was $76.07,77.88,80.06,82.98 \%$ and 83.64 over control $\left(\mathrm{V}_{1} \mathrm{~T}_{6}\right)$. Similarly, the lowest PDI was recorded from treatment $\mathrm{T}_{4}$ followed by $\mathrm{T}_{5}, \mathrm{~T}_{1}, \mathrm{~T}_{3}$ and $\mathrm{T}_{2}$ in $\mathrm{V}_{2}$ at 14 , 21 and at 28 days after first appearance of the disease. At 28 days after first 
appearance of the disease the reduction in PDI was 83.35, 80.72, 78.74, 78.46 and $78.37 \%$ under $\mathrm{T}_{4}, \mathrm{~T}_{5}, \mathrm{~T}_{1}, \mathrm{~T}_{3}$, and $\mathrm{T}_{2}$, respectively over control in $\mathrm{V}_{2}$ (Table 1).

Table 1. Efficacy of different fungicides against late blight of potato during 2012-13 crop season.

\begin{tabular}{|c|c|c|c|c|c|c|}
\hline \multirow{2}{*}{ Treatments } & \multicolumn{4}{|c|}{$\begin{array}{l}\text { Percent disease severity at } \\
\text { days after first spray }\end{array}$} & \multirow{2}{*}{$\begin{array}{l}\% \text { disease } \\
\text { reduction } \\
\text { over control }\end{array}$} & \multirow{2}{*}{$\begin{array}{l}\text { Yield } \\
\text { t/ha }\end{array}$} \\
\hline & 7 & 14 & 21 & 28 & & \\
\hline $\mathrm{V}_{1} \mathrm{~T}_{1}{ }^{*}$ & & $\begin{array}{c}9.45 \\
(18.39)^{* *}\end{array}$ & $\begin{array}{c}11.09 \\
(19.90)\end{array}$ & $\begin{array}{c}13.50 \\
(21.97)\end{array}$ & 76.07 & 22.56 \\
\hline $\mathrm{V}_{1} \mathrm{~T}_{2}$ & & $\begin{array}{c}8.97 \\
(17.92)\end{array}$ & $\begin{array}{c}10.60 \\
(19.46)\end{array}$ & $\begin{array}{c}12.48 \\
(21.12)\end{array}$ & 77.88 & 21.62 \\
\hline $\mathrm{V}_{1} \mathrm{~T}_{3}$ & & $\begin{array}{c}8.50 \\
(17.46)\end{array}$ & $\begin{array}{c}9.95 \\
(18.86)\end{array}$ & $\begin{array}{c}11.25 \\
(20.05)\end{array}$ & 80.06 & 23.89 \\
\hline $\mathrm{V}_{1} \mathrm{~T}_{4}$ & & $\begin{array}{c}7.04 \\
(15.94)\end{array}$ & $\begin{array}{c}8.49 \\
(17.45)\end{array}$ & $\begin{array}{c}9.23 \\
(18.18)\end{array}$ & 83.64 & 25.84 \\
\hline $\mathrm{V}_{1} \mathrm{~T}_{5}$ & & $\begin{array}{c}7.65 \\
(16.59)\end{array}$ & $\begin{array}{c}8.64 \\
(17.60)\end{array}$ & $\begin{array}{c}9.60 \\
(18.53)\end{array}$ & 82.98 & 24.89 \\
\hline $\mathrm{V}_{1} \mathrm{~T}_{6}$ & 18.42 & $\begin{array}{c}34.05 \\
(36.00)\end{array}$ & $\begin{array}{c}48.45 \\
(44.40)\end{array}$ & $\begin{array}{c}56.42 \\
(48.98)\end{array}$ & - & 16.50 \\
\hline $\mathrm{V}_{2} \mathrm{~T}_{1}$ & & $\begin{array}{c}8.65 \\
(17.61)\end{array}$ & $\begin{array}{c}9.64 \\
(18.57)\end{array}$ & $\begin{array}{c}11.30 \\
(20.09)\end{array}$ & 78.74 & 30.34 \\
\hline $\mathrm{V}_{2} \mathrm{~T}_{2}$ & & $\begin{array}{c}8.97 \\
(17.92)\end{array}$ & $\begin{array}{c}10.14 \\
(19.04)\end{array}$ & $\begin{array}{c}11.50 \\
(20.27)\end{array}$ & 78.37 & 28.51 \\
\hline $\mathrm{V}_{2} \mathrm{~T}_{3}$ & & $\begin{array}{c}8.32 \\
(17.28)\end{array}$ & $\begin{array}{c}10.94 \\
(19.77)\end{array}$ & $\begin{array}{c}11.45 \\
(20.22)\end{array}$ & 78.46 & 27.12 \\
\hline $\mathrm{V}_{2} \mathrm{~T}_{4}$ & & $\begin{array}{c}7.03 \\
(15.93)\end{array}$ & $\begin{array}{c}8.41 \\
(17.37)\end{array}$ & $\begin{array}{c}8.85 \\
(17.80)\end{array}$ & 83.35 & 27.56 \\
\hline $\mathrm{V}_{2} \mathrm{~T}_{5}$ & & $\begin{array}{c}7.49 \\
(16.42)\end{array}$ & $\begin{array}{c}9.57 \\
(18.50)\end{array}$ & $\begin{array}{c}10.25 \\
(19.14)\end{array}$ & 80.72 & 26.62 \\
\hline $\mathrm{V}_{2} \mathrm{~T}_{6}$ & 17.90 & $\begin{array}{c}32.76 \\
(35.22)\end{array}$ & $\begin{array}{c}45.23 \\
(42.55)\end{array}$ & $\begin{array}{c}53.17 \\
(47.10)\end{array}$ & - & 18.98 \\
\hline $\operatorname{SEm}( \pm)$ & & 0.66 & 0.59 & 0.74 & & 2.54 \\
\hline $\mathrm{CD}(\mathrm{P}=0.05)$ & & 1.37 & 1.23 & 1.53 & & 5.28 \\
\hline
\end{tabular}

*Abbreviations of $\mathrm{V}_{1} \& \mathrm{~V}_{2}$ and $\mathrm{T}_{1}-\mathrm{T}_{6}$ have mentioned in Section Materials and Methods

${ }^{* *}$ Figures within parentheses are angular transformed values. 
In variety $\mathrm{V}_{1}$, the highest total tuber yield was obtained with the treatment $\mathrm{T}_{4}$ followed by $\mathrm{T}_{5}, \mathrm{~T}_{3}, \mathrm{~T}_{1}$ and $\mathrm{T}_{2}$ showing the yield of 25.84, 24.89, 23.89, 22.56 and $21.62 \mathrm{t} \mathrm{ha}^{-1}$, respectively compared to control. In $\mathrm{V}_{2}$, the highest tuber yield was recorded from $\mathrm{T}_{1}$ followed by $\mathrm{T}_{2}, \mathrm{~T}_{4}, \mathrm{~T}_{3}$, and $\mathrm{T}_{5}$. Per hectare tuber yield was 30.34 , 28.51, 27.56, 27.12 and $26.62 \mathrm{t}$, respectively. In both varieties, the lowest yield of $16.50 \mathrm{t}$ was harvested from $\mathrm{V}_{1} \mathrm{~T}_{6}$ and $18.98 \mathrm{t}$ from $\mathrm{V}_{2} \mathrm{~T}_{6}$ (Table 1 ).

Table 2. Efficacy of different fungicides against late blight of potato during 2013-14 crop season

\begin{tabular}{|c|c|c|c|c|c|c|}
\hline \multirow[t]{2}{*}{ Treatments } & \multicolumn{4}{|c|}{$\begin{array}{c}\text { Percent disease severity at } \\
\text { days after first spray }\end{array}$} & \multirow{2}{*}{$\begin{array}{l}\% \text { disease } \\
\text { reduction } \\
\text { over control }\end{array}$} & \multirow{2}{*}{$\begin{array}{c}\text { Yield } \\
\text { t/ha }\end{array}$} \\
\hline & 7 & 14 & 21 & 28 & & \\
\hline $\mathrm{V}_{1} \mathrm{~T}_{1}^{*}$ & & $\begin{array}{c}10.48 \\
(18.89)^{* *}\end{array}$ & $\begin{array}{c}12.17 \\
(20.43)\end{array}$ & $\begin{array}{c}15.01 \\
(22.81)\end{array}$ & 77.84 & 23.59 \\
\hline $\mathrm{V}_{1} \mathrm{~T}_{2}$ & & $\begin{array}{c}9.50 \\
(17.95)\end{array}$ & $\begin{array}{c}11.89 \\
(20.17)\end{array}$ & $\begin{array}{c}14.29 \\
(22.22)\end{array}$ & 78.91 & 24.38 \\
\hline $\mathrm{V}_{1} \mathrm{~T}_{3}$ & & $\begin{array}{c}8.79 \\
(17.25)\end{array}$ & $\begin{array}{c}10.64 \\
(19.05)\end{array}$ & $\begin{array}{c}12.77 \\
(20.94)\end{array}$ & 81.15 & 25.49 \\
\hline $\mathrm{V}_{1} \mathrm{~T}_{4}$ & & $\begin{array}{c}7.91 \\
(16.33)\end{array}$ & $\begin{array}{c}8.91 \\
(17.38)\end{array}$ & $\begin{array}{c}10.30 \\
(18.72)\end{array}$ & 84.79 & 26.78 \\
\hline $\mathrm{V}_{1} \mathrm{~T}_{5}$ & & $\begin{array}{c}8.29 \\
(16.74)\end{array}$ & $\begin{array}{c}9.68 \\
(18.14)\end{array}$ & $\begin{array}{c}11.71 \\
(20.01)\end{array}$ & 82.71 & 26.28 \\
\hline $\mathrm{V}_{1} \mathrm{~T}_{6}$ & 21.58 & $\begin{array}{c}37.08 \\
(37.53)\end{array}$ & $\begin{array}{c}53.11 \\
(46.81)\end{array}$ & $\begin{array}{c}67.76 \\
(55.44)\end{array}$ & - & 17.49 \\
\hline $\mathrm{V}_{2} \mathrm{~T}_{1}$ & & $\begin{array}{l}10.07 \\
(18.50)\end{array}$ & $\begin{array}{c}11.62 \\
(19.94)\end{array}$ & $\begin{array}{c}14.34 \\
(22.26)\end{array}$ & 77.43 & 24.31 \\
\hline $\mathrm{V}_{2} \mathrm{~T}_{2}$ & & $\begin{array}{c}9.01 \\
(17.48)\end{array}$ & $\begin{array}{c}11.08 \\
(19.45)\end{array}$ & $\begin{array}{c}13.78 \\
(21.80)\end{array}$ & 78.31 & 25.97 \\
\hline $\mathrm{V}_{2} \mathrm{~T}_{3}$ & & $\begin{array}{c}8.61 \\
(17.07)\end{array}$ & $\begin{array}{c}10.38 \\
(18.80)\end{array}$ & $\begin{array}{c}12.26 \\
(20.50)\end{array}$ & 80.71 & 26.88 \\
\hline $\mathrm{V}_{2} \mathrm{~T}_{4}$ & & $\begin{array}{c}7.45 \\
(15.85)\end{array}$ & $\begin{array}{c}8.50 \\
(16.96)\end{array}$ & $\begin{array}{c}10.13 \\
(18.56)\end{array}$ & 84.06 & 28.69 \\
\hline $\mathrm{V}_{2} \mathrm{~T}_{5}$ & & $\begin{array}{c}7.83 \\
(16.26)\end{array}$ & $\begin{array}{c}9.03 \\
(17.50)\end{array}$ & $\begin{array}{c}11.18 \\
(19.54)\end{array}$ & 82.41 & 27.49 \\
\hline $\mathrm{V}_{2} \mathrm{~T}_{6}$ & 20.01 & $\begin{array}{c}33.58 \\
(35.43)\end{array}$ & $\begin{array}{c}50.47 \\
(45.30)\end{array}$ & $\begin{array}{c}63.56 \\
(52.90)\end{array}$ & - & 19.67 \\
\hline SEm ( \pm ) & & 0.35 & 0.39 & 0.59 & & 0.74 \\
\hline $\mathrm{CD}(\mathrm{P}=0.05)$ & & 0.72 & 0.80 & 1.21 & & 1.50 \\
\hline
\end{tabular}

*Abbreviations of $\mathrm{V}_{1} \& \mathrm{~V}_{2}$ and $\mathrm{T}_{1}-\mathrm{T}_{6}$ have mentioned in Section Materials and Methods

${ }^{* *}$ Figures within parentheses are angular transformed values. 
The results of 2013-14 crop season are presented in table 2. The finding reveal that in variety $\mathrm{K}$. Chandramukhi $\left(\mathrm{V}_{1}\right)$ the minimum PDI value was obtained with the treatment $\mathrm{T}_{4}(10.30 \%)$ followed by treatment $\mathrm{T}_{5}(11.71 \%)$ and $\mathrm{T}_{3}$. The highest PDI was recorded from control $\left(\mathrm{V}_{1} \mathrm{~T}_{6}\right)$. The percent reduction of the disease over control was 84.79 and $82.71 \%$ in treatment $\mathrm{V}_{1} \mathrm{~T}_{4}$ and $\mathrm{V}_{1} \mathrm{~T}_{5}$ respectively at 28 days first appearance of the disease. The highest total tuber yield of $26.78 \mathrm{t} \mathrm{ha}^{-1}$ was recorded in treatment $\mathrm{V}_{1} \mathrm{~T}_{4}$ followed by treatment $\mathrm{V}_{1} \mathrm{~T}_{5}$.

In variety $\mathrm{K}$. Joyti $\left(\mathrm{V}_{2}\right)$ the lowest PDI was also observed in treatment $\mathrm{V}_{2} \mathrm{~T}_{4}$ (10.13) followed by treatment $\mathrm{V}_{2} \mathrm{~T}_{5}$ where percent disease severity was 11.18 . The highest PDI was found in treatment $\left(\mathrm{V}_{2} \mathrm{~T}_{6}\right)$ where percent disease severity was $63.56 \%$ at 28 days after first appearance of the disease. The treatment $\mathrm{V}_{2} \mathrm{~T}_{4}$ and $\mathrm{V}_{2} \mathrm{~T}_{5}$ showed 84.06 and $82.41 \%$ reduction in PDI, respectively. The highest total tuber yield of $28.69 \mathrm{t} \mathrm{ha}^{-1}$ was also obtained with the treatment $\mathrm{T}_{4}$ in variety $\mathrm{V}_{2}$ followed by treatment $\mathrm{T}_{5}$ where total tuber yield was $27.49 \mathrm{t} \mathrm{ha}^{-1}$.

The findings found in the present investigation are in agreement with the findings of De and Sengupta, 1988 and 1991 who observed that mancozeb and combined product of systemic and contact fungicide may have synergistic effect against $P$. infestans. Baider and Cohen (2003) also reported that combination of mancozeb with beta amino butyric acid (BABA) has synergistic effect against $P$. infestans in potato and tomato than either of them alone. Chakraborty and Majumder (2012) also observed that late blight can effectively be managed by adopting prophylactic spray with mancozeb @ $0.25 \%$ followed by cymoxamil + mancozeb @ $0.3 \%$ at the onset of the disease followed by mancozeb @ $0.25 \%$ seven days after application of systemic fungicide.

\section{CONCLUSION}

Based on findings of the present experiment it may be concluded that the late blight of potato can effectively be managed by applying prophylactic spray (just at the time of canopy closure) with mancozeb @ $0.2 \%$ followed by fenamidone + mancozeb@0.3\% as $2^{\text {nd }}$ spray at the onset of the disease followed by mancozeb @ $0.2 \%$ as $3^{\text {rd }}$ spray seven days after the application of $2^{\text {nd }}$ spray followed by femanidone + mancozeb @ $0.3 \%$ as $4^{\text {th }}$ spray seven days after the application of $3^{\text {rd }}$ spray.

\section{REFERENCES}

Baider, A. and Cohen, Y. 2003. Synergistic interaction between BABA and mancozeb in controlling Phytophthora infestans in potato and tomato and Pseudoperonospora cubensis in cucumber. Phytoparastica, 31(4): 399

Chakraborty, A. and Mazumdar, D. 2012. Development of effective spray schedule for the management of late blight of potato in plains of West Bengal. Potato Journal, 39(1): 92-94 
De, B. K. and Sengupta, P. C. 1988. Studies on spray schedule of fungicide against late blight disease of potato caused by Phytophthora infestans. Indian Agriculturist, 32: 1-17

De, B. K. and Sengupta, P. C. 1991. Evaluation of fungicide against late blight disease of potato in plains of West Bengal. Journal of Indian Potato Association, 18: 176-177

Dutt, B. L. 1979. Bacterial and fungal disease of potato. ICAR, New Delhi

Elansky, S. N., Smirnov, A. N., Dyakov, Y., Doglova, A., Filippov, A., Kozlovsky, B., Kozlovskaya, I., Russo, P., Smart, C. and Fry, W. E. 2001. Genotypic analysis of Russian isolates of Phytophthora infestans from the Moscow region, Siberia, and Far East. Journal of Phytopathology, 149: 605-611

Malcolimson, J. F. 1976. Assessment of field resistance to late blight (Phytophthora infestans) in potatoes. Transactions of the British Mycological Society, 67: 321-325

McKinney, H. H. 1923. Influence of soil temperature and moisture on infection of wheat seedlings by Helminthosporium sativum. Journal of Agricultural Research, 26: 195217

Singh, P. H., Singh, B. P. and Singh, L. 2003. Need based application of fungicides for management of late blight of potato. Journal of Indian Potato Association, 30(1-2): 143-144 